\title{
Arterial Insufficiency
}

National Cancer Institute

\section{Source}

National Cancer Institute. Arterial Insufficiency. NCI Thesaurus. Code C127821.

A condition in which there is inadequate blood flow through an artery. 